\title{
PECULIARITIES OF FUNCTIONING OF POLYPROPOSITIONAL REFERENTIALLY SPECIALIZED VERBAL PREDICATES IN UKRAINIAN, POLISH, AND ENGLISH (A CORPUS-BASED APPROACH)
}

\author{
Roksolana Nazarchuk \\ Senior Lecturer, Lviv Polytechnic National University, Ukraine \\ e-mail: roksolana.z.nazarchuk@1pnu.ua,orcid.org/0000-0002-0482-2883
}

\section{Summary}

The article analyzes the object relations of referentially specialized verbal predicates in Ukrainian, Polish, and English, identified with the involvement of functional-onomasiological methodology. We present the most common views in linguistics on the semantics of the verb as the propositional meaning core and the argument frame determinant, and, consequently, as a basis for modelling cognitive-propositional structures. In particular, a reference is made to the approaches within Ch. Fillmore's Case Grammar and Frame Semantics, D. Dowty's theory of proto-roles and argument selection, R. D. Van Valin's Role and Reference Grammar, B. Levin's perspectives on the event structure and argument realization, and others. Peculiarities of propositions that form referentially specialized verbal predicates in Ukrainian, Polish, and English are considered. Based on the Ukrainian, Polish, and English text corpora data (GRAC, NKJP, BNC), typical situations of the denotative complex "Damaging an inanimate object" are analyzed in detail. We discovered the combination of the following procedure- and event-driven situations: physical impact, pressure, the object integrity violation, destruction, the object attribute changes, the object position changes, separation, movement, touching, coating, etc. and provided examples from the text corpora. It is shown how metaphorical transfers cause the appearance of atypical items in their semantics with referentially specialized verbal predicates in Ukrainian, Polish, and English.

Keywords: semantics, proposition, object, functional-onomasiological analysis, text corpus.

\section{DOI: https://doi.org/10.23856/3811}

\section{Introduction}

The propositional type of knowledge representation has often been the focus of linguists. The principles of studying and describing the predicate connection with arguments and dependence of the argument semantic, morphological, and syntactic features on the predicate semantics were considered in the researches by J. Apresjan (Apresjan, 2009), R. Van Valin (Van Valin, 1999, 2005, 2014), D. Dowty (Dowty, 1991, 2000), J. Grimshaw (Grimshaw, 1990), R. Jackendoff (Jackendoff, 1990), W. Croft (Croft, 1998), B. Levin (Levin, 2005, 2015), Ch. Fillmore (Fillmore, 2009), I. Schlesinger (Schlesinger, 1995), and others. However, despite the great variety of interpretations, there are still many research gaps, which determines the topicality of our study. The aim of this research is to investigate the object relations of referentially specialized verbal predicates in Ukrainian, Polish, and English, to consider the propositional complexes that form the mentioned predicates by analyzing the text corpus data, as well as to identify their communicative features. The scientific novelty consists in combining for the first time the structural-semantic and functional-onomasiological contrastive analysis, as well as the corpus-based approach. 


\section{Analysis Procedure}

\section{The verb meaning in the light of semantic-syntactic theories}

The verb manifests the dynamic aspect of being, and the verbal predicate semantics as the propositional semantic core determines its valence, and hence the consistency of appearance in the propositional structure of arguments with a certain logical semantics. After all, an action is a coordination center that regulates the relationship between the human being and the world (Langacker, 1987: 54), and the verb as the most regular predicate sign is a "compact name for situations and structures of reality which inevitably entail an idea of the most important components of the marked activity structure" (Selivanova, 2000: 135). Researchers often define the verb essence as a significative-denotative one. Procedural, relational meaning is a significative part of the verb semantics, while the verb denotation is the idea of the situation containing the information about its participants, their physical, quantified, axiological features and sometimes their circumstantial characteristics; for each occurrence, the verb denotes a situation with a distinct set of participants; the verb semantics includes an indication of these participants' properties and their relations: "The lexical entry of a verb will comprise various participants in the activity, event or state referred to by the verb" (Schlesinger, 1995: 58).

In the context of cognitive linguistic research, the issues of verbal semantics come into a special focus. The representatives of cognitive semantics consider the verb meaning as such that motivates the indicated situation with its conceptual content and interpret it as a means of access to the cognitive-propositional structures of the respective concepts, as well as the basis for their modeling. It is known that the knowledge representation structures are "conditional and simplified models of the consciousness representing multifarious information acquired through various human mental cognitive mechanisms in the interaction of the human being with the world and in the process of inner reflection" (Selivanova, 2008: 390). Thus, the propositional model as a knowledge representation structure (along with frames, scenarios, scripts, prototypes, etc.) is the center of interest of the cognitive scientific paradigm. It receives a special interpretation within the Case Grammar and Role and Reference Grammar approaches. M. Minsky's concept interpretation and its transfer from the realm of artificial intelligence to the linguistic field contributed to the frame semantics development. In fact, Ch. Fillmore identified the frame as a proposition, a predicate-argument structure, and applied the concept of frame to describe the semantic roles of the situation components as a case structure and to understand new information based on this structure's template (Selivanova, 2008: 645). According to B. Levin (Levin, 2005), the work by R. Dixon on ergativity (Dixon, 1979) became the starting point of generalized semantic roles. The author interprets the relations of the subject/object with the predicate as syntactic-semantic primes. An attempt to apply the concept of prototype to the analysis of the predicate-argument structure was also made by G. Lakoff (Lakoff, 1970). A little later, P. J. Hopper (Hopper, 1980) applied the prototype to the concept of transition, and R. Langacker considers the position of a subject and an object with a transitive verb as a conceptual archetype (Langacker, 1993: 486-497). It is worth mentioning D. Dowty's proto-role approach, which found a considerable support in the further research (Dowty, 1991, 2000), but did not develop into a separate grammatical theory as it focused on the analysis of basic verbs and the material of almost exclusively the English language (an analytical one). The American linguist's center of attention was primarily the role of the subject-agent, which D. Dowty interpreted as hierarchically superior and pragmatically significant, considering the right-wing arguments lower in rank.

A significant step forward in designing arguments and interpreting the clause meaning was made within the Role and Reference Grammar (Van Valin, 1999, 2005, 2014). It should be 
noted that the R. D. Van Valin's structural-functional theory is based on typological studies and data of various languages and, according to B. Levin and M. Rappaport Hovav, it is postulated as a global semantic-syntactic theory that claims to analyze the language as a whole, and is therefore scientifically promising (Levin \& Rappaport Hovav, 2005: 66-67).

Attempts to model cognitive-propositional structures have important practical application. In particular, the most important achievement of frame semantics was the English-based FrameNet project created by Ch. Fillmore at the International Institute of Computer Science in Berkeley. It is also necessary to mention VerbNet projects for the English language (based on an extension of B. Levin's theory) and PropBank structure network (by P. Kingsbury and M. Palmer).

\section{II.Object relations of referentially specialized verbal predicates}

The relativity of the semantic nature of the verb, which in its latent form often contains an internal semantic subject/object, was aptly outlined by R. Langacker. In his research, he also noted that one must determine the inanimate physical object, a thing, as the object category prototype (Langacker, 1987: 54). Thus, further remarks concern the referentially specialized verbal predicates in Ukrainian, Polish, and English (i.e., verbal predicates with limited denotative correlation, the semantics of which determines the physical properties of the object as the body embedded in its name), identified using functional-onomasiological methodology proposed by F. Batsevych (Batsevych, 1997). Certain functional groups were distinguished, including verbs that reflect the physical properties of a substance: liquidity - бризкати (водою), сеdzić (mleko), to soak (in liquid); hardness - довбати (камінь), piłować (drzewo), to rag (stone, ore); gaseousness - відводити (газ), wdychać (powietrze), to puff (smoke); the exterior shape features - котити, katulać (something round), to thirl (with a sharp-pointed tool); здувати (something light); ciagnać, to heft (something heavy); some other substance characteristics: flowability — nрuсunamu, zapryszyć, to gravel; flexibility, torquability — мотатu, prąń, to kink, etc.

Structural-semantic and cognitive analysis of the Russian verbal vocabulary allowed L. Babenko to distinguish between simple, monopropositional, and complex, polypropositional verbs (Babenko, 1999: 32-33). The former represent knowledge of typical situations in the most condensed form, such as: motion verbs (to move, to ascend, to shift), striking (to beat, to strike), being (to be, to exist). To the latter L. Babenko refers verbs with included and shifted proposition that most comprehensively express our ideas about the regular relations of situations that mark various aspects of the course of events: place, time, causality, etc. Polypropositional verbs have a unique ability to blur the boundaries between different denotative spheres and bring distant situations closer into a single complex (Babenko, 1999: 20). For example, in the verb нанизувати (by piercing and stabbing any small objects (mostly a certain number of them) to fit, bead them on a thread, lace, etc., connecting them) along with the main proposition of the connection there are propositions of violating the object integrity, creative activity, etc., which are linked by a complex of universal logical-semantic connections: causative-consecutive, those of manner and purpose. The analysis showed that most of the studied referentially specialized verbs in Ukrainian, Polish, and English are polypropositional.

\section{Verbal predicates of complex polypropositional semantics in Ukrainian, Polish, and English text corpora}

Characterizing the features of the relations of the verbal predicate and the object, we consider it appropriate to use a corpus-based approach which, according to researchers, ensures 
the objectivity of the results and prevents introspective interpretation: "the standard procedures for accessing corpora (concordances, collocate lists, frequency lists) are a natural step towards identifying the relevant distributions in the first place" (Stefanowitch, 2020: 59).

A detailed analysis of referentially specialized polypropositional verbal predicates in Ukrainian, Polish, and English text corpora shows that such verbs differ both in the number of propositions contained in their semantics and in the nature of logical-semantic connections that combine eventive propositions in their semantics. For example, the denotative complex "Damaging an inanimate object" contains the following typical situations:

1) physical impact, pressure, destruction. E.g.: вигризати (..своӥми зубами Борис, і Вітько подумав, щуо, мабуть, ними добре кавун вигризати: вперед стремлять, $і$ свої, $i$ вставлені [GRAC]); кусати (То бігала, якби шалена, Стояла довго тороплена, Кусала ногті на руках [GRAC]); gryźć (Chłopiec gryzie kostkę cukru powoli, nie otwierając oczu [NKJP]); grind (That building in the corner housed the old portable steam-engine that $\mathrm{Mr}$ Webster the miller later bought: he used to grind the corn there when there was no wind [BNC]); gnaw (They were so poor that they had to grind up the bark of trees to make flour for their bread $[\mathrm{BNC}])$;

2) striking, object integrity violation/destruction. E.g.: розбивати (На теплого Олексія, кажуть, щука-риба лід хвостом розбиває [GRAC]); роздовбувати (хто знає, може, кілька років тому один з них брав участь у розкуркулюванні й колективізації, роздовбував долівку хати, розкопував подвір'я, шукаючи захованого хліба [GRAC]); wydtubywać (Raz za razem ostrze wydlubywało kawałki cementu [NKJP]); pierce (Leave a $1 \mathrm{~cm}$ in shell - do not pierce the skin [BNC]); goug (Sweetman turned a furious smeared face at us, then drove his garish boat hard at Wavebreaker's hull to gouge a long scratch down to the bare metal [BNC]; Dul was to slip into the sea, then, binding the container of burning pitch to his head with a deep cushioning of reeds in between to prevent him getting burned, he would swim to the ship, gouge a hole in the hull with his knife and, taking dry tinder from a companion swimming alongside him, light spills from the fire [BNC]);

3) pressure, physical impact, object integrity violation, movement. E.g.: nopnamu (Обидва пси стали порпати долівку [GRAC]); розрихлювати (...я почав копати обережно, щуоб не зламати ножа, розрихлював землю й вигрібав ї̈ уламком від драбини та руками [GRAC]); ryć (rumaki rycerzy ryły podkowami ziemię wokół wozu [NKJP]); rozkopywać (Buciki rozkopują mokry piasek [NKJP]); dig (I was much too small to climb their trees, or dig their fields, or kill and eat their animals [BNC]);

4) object integrity violation, object position change, and disintegration. E.g.: ламати (Раптом ламає об коліно свою подорожню палицюю [GRAC]; Та в городі тепер не до новин; там так старі доми ламають, та улиці застроюють новими домами, та кришки красять... [GRAC]); лупати (...от тільки каменярам не буде там чого робити, бо вони або лупають чи довбають скелі, прокладаючи в горах дорогу... [GRAC]); rozłupywać (Fach $w$ jego rodzinie przechodził z pokolenia na pokolenie, i kat nie chciat przynieść wstydu przodkom, dlatego z zapałem rozłupywał kłody drzewa, rozważał sposób najlepszego ułożenia głowy na pieńku, ostrzyt swoje narzędzie, aż błyszczało w słońcu [NKJP]; Teraz nawet, idac do stajni, do stodoły czy też rozłupywać sosnowe okraglaki, bytem wystrojony, jakbym szedt na odpust [NKJP]); przełamywać (Wyjmuje mu czekoladę z ręki, rozwija opakowanie, przełamuje czekoladę na dwie części [NKJP]); chop (Chop the onion, garlic, carrot and celery and put into a casserole [BNC]; Chop cheese into small cubes [BNC]);

5) touching, covering. E.g.: мастити (...хворий спокійно відповів: “Мені болить голова, от я $і$ мащу ї̈ мастю; а білих ліків мені не треба ковтати: вони в живіт 


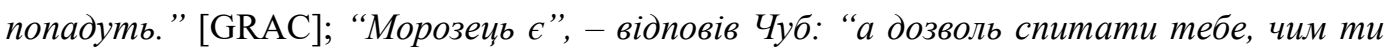
мастиш собі чоботи, смальцем чи дьогтем?” [GRAC]); имарувати (бо мене вважають за відьму. Сусіди барикадують з вулииі мої двері, имарують поріг мого дому дьогтем $i$ заклеюють вікна папером [GRAC]); smarować (W środku czeka już kobieta z wielka torba, smaruje sobie nogi kremem na moskity [NKJP]; Metodycznie smarowat bułke mastem, watrobianka i uktadat na tym wszystkim plastry szynki [NKJP]) ; tynkować (Sprzatacze szorowali podłogi zdzierając z parkietów plamy wsiąkej krwi, lokaje zdejmowali poszarpane i nadpalone kotary, ciężarówki wywoziły sterty potrzaskanych mebli i skrzynie pustych tusek, szklarze wstawiali nowe szyby i lustra, murarze tynkowali wyszczerbione kulami ściany [NKJP]); smear (Visitors often smear the mud on their bodies [BNC]; In nineteenth-century Paris young revellers would melt down chocolate and smear horrified passers-by with what they took to be excrement [BNC]); spread (He cut another slice of bread and spread the butter on it from edge to edge very carefully before he took a big bite [BNC]; She spread mulberry jam in reckless bounty upon a slice of tea cake [BNC]);

6) pressure, change of an attribute. Е.g.: Напр.: м'яти (М'яв недопалок цчигарки, розтоптуючи його в попільничи̧і [GRAC]; ...вертиться, просить розгоститися, а він наче на грані стоїть, капелюх в руках мне, одно лиш на землю споглядає [GRAC]); чавити (I вже кінь скаче на луки, чавить копитами траву, аж бризкає із неї сік [GRAC]; Надька коло столу, чавить калину, а потім, підвівши голову хворому, пӧ̈ь його з кухля [GRAC]); wyciskać (Postanowiłem już nie wyciskać tej cytryny [NKJP]; Tarła $i$ wyciskała szmaty, aż woda pryskała na wszystkie strony [NKJP]); gnieść (Strugała kartofle, gniotła ciasto na kluski $i$ nagle zaczynała płakać [NKJP]); squeeze (Squeeze the lemon and blend the juice with crushed raspberries in large jug [BNC]; Fill and squeeze plastic bottles to show propulsion [BNC]); knead (Knead the dough until it becomes smooth and elastic [BNC]).

Thus, the intersection of the verb and object occurs within the deep structure of the predicate, where there are places for objects of certain semantics and denotative mood, and this is confirmed by the patterns of the verbal predicate communicative orientation on certain characteristics of their objects. At the same time, due to the cognitively various metaphorical transfers, verbal predicates often "adopt" objects from atypical functional-onomasiological spheres, which is proved by the text corpora data. Let's consider frequencies of object collocates from the GRAC, NKJP, and BNC: ламати (крига 49; стереотип (figurative) 82); розбивати (стіна 43; серце (figurative) 111); wyciskać (woda 16; łzy (figurative) 102); gryźć (palka 35; oczy (figurative) 112); spread (bread 37; news (figurative) 44); squeeze (lemon 12; money (figurative) 8).

Let's compare: Чогось я й не прикидаю, щуо ти будеш папір шмарувати всякими там репортажами та інтерв'ю [GRAC]; Матвія духота з печі жене, дим очі вигризає [GRAC]; ...za to, żeś razem z swym kompanem wyciskal siódme poty ze mnie [NKJP]; Wiatr wyciska mi tzy z oczu - dlatego té czasami zamykam je na krótkie chwile [NKJP]; They were jealous of his success, they spread rumours about him [BNC]; The dank smell of the water was not unpleasant, and for years the scent of la Sologne that enveloped me that night would pierce my memory: a combination of stagnant water, slime, wild mushrooms, wispy dry grasses, sand and well-hung game [BNC].

\section{Conclusions}

The study of the semantics of referentially specialized polypropositional verbal predicates reveals a fixed knowledge of the regular interaction of typical situations of the 
procedure- and event-driven world. Thus, the denotative complex "Damaging an inanimate object" in Ukrainian, Polish, and English is heterogeneous; it involves a combination of situations of physical influence, pressure, object integrity violation, destruction, object attribute change, object position change, disintegration, movement, touching, coating, etc. The text corpora data of the studied languages record a significant number of metaphorical transfers resulting from the comprehension of some object spheres through the prism of others and result in the appearance of semantically atypical items with referentially specialized verbal predicates.

The methods used enhance the understanding of the principles governing the speaker's utterance proposition formation, make it possible to approach the cognition of mental operations of grasping the reality and the connections between linguistic and conceptual pictures of the world, can be useful for creating communicative grammars of national languages and solving many issues of contrastive semantics and the speech activity theory, and therefore open the prospect of further scientific research.

\section{Abbreviations:}

BNC - British National Corpus (2020, July 18). Retrieved from https:// www.english-corpora.org/bnc

GRAC - The General Regionally Annotated Corpus of Ukrainian (2020, July 18). Retrieved from uacorpus.org

NKJP - Narodowy Korpus Języka Polskiego (2020, July 18). Retrieved from http://www.nkjp.uni.lodz.pl/index.jsp

\section{References}

Apresjan, J. D. (2009). Issledovaniya po semantike i leksikografii [Research in semantics and lexicography]. Moscow: Yazyki slavyanskih kultur. [in Russian]

Babenko L. G. (1999). Denotativnoe prostranstvo glagolov kompleksnoj polipropozitivnoj semantiki [Denotative space of verbs with complex polypropositional semantics]. In L. G. Babenko (Ed.), Russkaya glagolnaya leksika: denotativnoe prostranstvo [Russian verbal vocabulary: denotative space] (pp. 172-195). Ekaterinburg: UrGU. [in Russian]

Batsevych, F. S., Kosmeda, T. A. (1997). Ocherki po funkcionalnoj leksikologii [Essays on functional lexicology]. Lviv: Svit. [in Russian]

Croft, W. (1998). Event structure in argument linking. In M. Butt \& W. Geuder (Eds.), The projection of arguments: lexical and syntactic constraints (pp. 21-63). Stanford U-ty Press.

Dixon, R. M. W. (1979). Ergativity. Language, 55, 59-138.

Dowty, D. R. (2000). 'The garden swarms with bees' and fallacy of 'argument alternation'. In Y. Ravin \& C. Leacock (Eds.), Theoretical and computational approaches (pp. 111-128). Oxford University Press.

Dowty, D. R. (1991). Thematic proto-roles and argument selection. Language, 67, 547-619.

Fillmore, Ch. J. (2009). A frames approach to semantic analysis. In B. Heine \& H. Narrog (Eds.), The oxford handbook of linguistic analysis (pp. 313-340). Oxford University Press.

Grimshaw, J. (1990). Argument structure. The MIT Press.

Hopper, P. J. (1980). Transitivity in grammar and discourse. Language, 56, 251-295.

Jackendoff, R. (1990). Semantic structures. The MIT Press.

Lakoff, G. (1970). Irregularity in Syntax. Holt, Reinhart \& Winston.

Langacker, R. W. (1993). Clause structure in cognitive grammar. Studi Italiani di Linguistica Teorica e Applicata, 22, 465-508. 
Langacker, R. (1987). Nouns \& Verbs. Language, 63 (1), 53-93.

Levin, B., Hovav, M. R. (2005). Argument realization. Cambridge University Press.

Levin, B. (2015). Semantics and pragmatics of argument alternations. Annual Review of Linguistics, 1, 63-83.

Schlesinger, I. M. (1995). On the semantics of the object. In B. Aarts \& Ch. F. Meyer (Eds.), The verb in contemporary English. Theory and description (pp. 54-74). Cambridge University Press.

Selivanova, Je. (2000). Kognitivnaya onomasiologiya [Cognitive onomasiology]. Kyiv: Fitosociotsentr. [in Russian]

Selivanova, O. (2008). Suchasna lingvistyka: napryamy ta problemy [Modern linguistics: trends and problems]. Poltava: Dovkillya -K. [in Ukrainian]

Stefanowitch, A. (2020). Corpus linguistics: a guide to the methodology. Language Science Press. Van Valin, R. D. (2005). Exploring the syntax-semantic interface. Cambridge University Press. Van Valin, R. D. (1999). Generalized semantic roles and the syntax-semantic interface. In F. Corblin, C. Dobrovie-Sorin, \& J. Marandin (Eds.), Empirical issues in formal syntax and semantics (pp. 373-389). Thesus.

Van Valin, R. D. (2014). Role and reference grammar. In A. Carnie, Y. Sato, \& D. Siddiqi (Eds.), Routledge handbook of syntax, (pp. 579-603). Routledge. 